\title{
FORUM:
}

\section{CLOSENESS AND DISTANCE IN THE AGE OF ENLIGHTENMENT INTRODUCTION}

\author{
JOHN BREWER* AND SILVIA SEBASTIANI** \\ ${ }^{*}$ Division of Humanities and Social Sciences, California Institute of Technology \\ E-mail: jbcaltech@yahoo.com \\ ${ }^{* *}$ Ecole des hautes études en sciences sociales, Paris \\ E-mail: silvia.sebastiani@ehess.fr
}

A duly qualified man can obtain more knowledge of India in one year in his closet in England than he could obtain during the course of the longest life, by the use of his eyes and ears in India. ${ }^{.}$

Historical truth is, as it were, rather like the clouds which take shape for the eye only at a distance. $^{2}$

Writing speaks of the past only in order to inter it. ${ }^{3}$

According to Michel de Certeau, distance is the indispensable prerequisite for historical knowledge and the very characteristic of modern historiography. The historian speaks, in the present, about the absent, the dead, as Certeau labels the past, thus emphasizing the performative dimension of historical writing: "the function of language is to introduce through saying what can no longer be done."4 As a consequence, the heterogeneity of two non-communicating temporalities becomes the challenge to be faced: the present of the historian, as a moment $d u$ savoir, is radically separated from the past, which exists only as an objet de savoir the meaning of which can be restored by an operation of distantiation and

James Mill, The History of British India, vol. 1 (London, 1817), xv.

2 Wilhelm von Humboldt, "On the Historian's Task" (1821), History and Theory, 6/1 (1967), $57-71,58$.

3 Michel de Certeau, The Writing of History, trans. Tom Conly (Néw York, 1988; first published 1974), 101.

$4 \quad$ Ibid., emphasis in the original. 
contextualization. ${ }^{5}$ In Evidence de l'histoire: Ce que voient les historiens, François Hartog takes up the question of history writing and what is visible, or more precisely the modalities historians have employed to narrate the past, opening up the way to a reflection on the boundaries between the visible and the invisible: the mechanisms that have contributed to establish these boundaries over time, and the questions that have legitimized the survey of what has been seen or not seen. ${ }^{6}$ But, as Mark Phillips points out, it is the very ubiquity of the trope of distance in historical writings that has paradoxically rendered it almost invisible to historians, so that "it has become difficult to distinguish between the concept of historical distance and the idea of history itself."7

The issues around the question of historical distance, though they have a long pedigree that goes back to antiquity, ${ }^{8}$ intensified in the age of Enlightenment when, as Reinhart Kosellek has argued, eighteenth-century understandings of change as progress produced not only an accelerated sense of time, but a strong sense that history was not so much a question of identifying exemplary moments in the past (chiefly for the instruction of contemporary rulers), but rather a matter of charting and explaining historical change through continuous time. ${ }^{9}$ The question at issue was how the historian, in the present, should account for a past that necessarily had a connection to the present and, in as much as such a view was underpinned by a desire to understand the science of man, such history necessarily had universal aspirations and claims. The history of any society was necessarily a commentary on the history of other societies, all of which could be evaluated - through comparison-on a developmental timeline. Edmund Burke's "great map of mankind" was a geographical instantiation of history, enabling its viewers to ask "what time is this place," a question that was only possible because of the absence, presence and extent of the red thread of progress. ${ }^{10}$ Historical chronology and geographical space were necessarily

5 As Antoine Lilti notes in relation to Lucien Febvre's historiography. See "Rabelais est-il notre contemporain? Histoire intellectuelle et herméneutique critique," Revue d'histoire moderne et contemporaine, 59/4bis (2012), 65-84, 71. See also Carlo Ginzburg, "Distance and Perspective: Two Metaphors," in Ginzburg, Wooden Eyes: Nine Reflections on Distance, trans. Martin Ryle and Kate Soper (New York, 2001), 139-56.

$6 \quad$ François Hartog, Evidence de l'histoire: Ce que voient les historiens (Paris, 2005); Hartog, Régimes d'historicité: Présentisme et expériences du temps (Paris, 2002).

7 Mark Salber Phillips, "Distance and Historical Representation," History Workshop Journal, 57 (2004), 123-41, 125. See now Phillips, On Historical Distance (New Haven, 2013).

8 François Hartog, Le miroir d'Hérodote: Essai sur la représentation de l'autre (Paris, 1980).

$9 \quad$ Reinhart Koselleck, Futures Past: On the Semantics of Historical Time, trans. Keith Tribe (New York, 2004; first published 1979).

10 Edmund Burke to William Robertson, 9 June 1777. See The Correspondence of Edmund Burke, vol. 3, ed. George H. Guttridge (Cambridge, 1961), 351. 
intertwined. Difference was both geographically locatable and identifiable as a point on the timeline of progress.

All five of the essays in this collective inquiry into the question of historical distance address the dilemmas posed by this linear, progressive view of the past, first fully elaborated in the Enlightenment and still very much alive today. They originated as contributions to a workshop on Closeness and Distance in the Age of Enlightenment that was part of Caltech's Mellon-funded project on the nature of evidence." Mark Phillips uncovers the process by which exemplary "history painting" was molded anew as a story of national progress and achievement. Miles Ogborn examines the tensions between the natural and civil histories of Jamaica and how they map onto a debate about savagery and civility that was racially inflected. John Brewer unravels the strategies of the philosophical travel writer who struggled to reconcile alterity with sympathetic understanding. Silvia Sebastiani analyses two different histories of the Americas, one in the Enlightened philosophical tradition, the other committed to the particularism of Creole and Jesuit antiquarianism. Jonathan Sachs concludes with a study in eighteenth-century time scales, showing how scale, distance and interpretation were interconnected both textually and in graphic form.

The essays are all, in their different ways, explicit meditations on the work . of one of the contributors, Mark Phillips, on historical distance. As a scholar of historiography and (Scottish) Enlightenment social theory (though his analysis extends to other fields), Phillips has used his subtle readings of the works' of the likes of David Hume to elaborate what he has called a "liberal heuristic" of distance, one that recognizes that historical practice, both in the past and in the present, can be understood as a finely modulated exercise in mediation which moves beyond a view in which time and space are treated as transparently open to objective measurement. This in no way denies that he-and the other contributors to this collection-are not mindful of the conceptual and epistemological issues raised by historical distance. ${ }^{12}$ The object here, however, is

1 Closeness and Distance in the Age of Enlightenment, a Mellon Conference, The Temper of Evidence, 27-8 May 2011, California Institute of Technology. The overall Mellon-funded project, directed by John Brewer, Jed Buchwald and Mordechai Feingold, was The Temper of Evidence, from Antiquity through the Eighteenth Century. Other publications include Reason, Evidence and Erudition in Early Modern Europe, a special issue of the Huntington Library Quarterly, 74, 3 (2011), and Matter and Form in Early Modern Science and Philosophy, ed. Gideon Manning (Leiden and Boston, 2012).

12. See, from a large literature, the recent special issue on Historical Distance: Reflections on a Metaphor, History and Theory, 50/4 (2011), 1-149, where "historical distance" is analyzed as a metaphor which has ontological, epistemological, moral, aesthetic, and methodological connotations, and is used in a variety of intellectual contexts. See also the session dealing with distance and proximity in historical imagination in History Workshop Journal, 57 
606 "JOHN BREWER AND SILVIA SEBASTIANI

not to arbitrate over optimal forms of distantiation, but rather to historicize the uses of distance, to examine their employment in a number of eighteenth-century cases and controversies. As Phillips puts it more generally, "when distance sheds the burdens of prescription, the idea is free to take on a layered complexity that resists rigid and artificial distinctions." This also requires that we treat distànce as "the entire dimension of representation rather than one extremity or limit."13 Once this emancipatory move is made, we are in a position to elaborate the ways in which distance can be deployed historically. These, Phillips argues, are best understood as issues of representation, affect, ideology, and cognition (basic assumptions about explanation and understanding), or what he refers to as form, affect, summoning, and understanding.

The most conspicuous mode of historical representation found in the following essays is the approach generally characterized as Enlightened "philosophical history," a project that seeks to take a universal view that, at the same time, tracks difference as manifested by different levels of progress and social development. Thus, as Sebastiani reminds us, the historical observer for Voltaire is an extraterrestrial, and for Turgot an observer from the Moon using a telescope to move from the most general to the particular. The viewer stands outside and, in some sense, above the phenomenon observed, and in this way achieves the sort of detachment deemed necessary for historical analysis and philosophical understanding. This is the position of such disparate figures in our discussion as Edmund Burke, the Rev. William Robertson, Dr John Moore, Jean-Jacques Rousseau, Adam Smith and Edward Gibbon. The one conspicuous exception to this approach is that of Robertson's antagonist, the Mexican exiled Jesuit Francisco Javier Clavijero. His Storia antica del Messico (1780-81), though certainly covering a large time span (from the sixth to the sixteenth centuries), nevertheless constitutes an explicit rejection of 'philosophical history' for an antiquarian approach that emphasized closeness rather than distance, local expertise rather than textual knowledge, and direct observation rather than written testimony.

The sort of philosophical history that Clavijero opposed was, as Jonathan Sachs emphasizes, committed to the longue durée, to the notion that reordering or extending time scales-looking both from and at a long distance-facilitated impartial and detached observation. Thus the apparent short-term decline, whether of ancient Rome or modern Britain, that produced sententious

(2004), 117-49; Mark Salber Phillips, "Histories, Micro- and Literary: Problems of Genre and Distance," New Literary History, 34 (2003), 211-29; John Brewer, "Microhistory and the Histories of Everyday Life," Cultural and Social History, 7/1 (2010), 87-109, which emphasizes issues of perspective, space, size and historical distance in shaping historical interpretation. 
jeremiads, was transformed by Gibbon and Smith, through the simple expedient of extending the time frame of analysis, into a local fluctuation in a history that was, viewed dispassionately and in the long term, one of progress. In certain respects Playfair's charts and graphs represent the apogee of this compression of long-term data into present history.

Of course the issue of detachment and distance was-as it still remains-a rather more fraught one than such a straightforward analysis implies. As Brewer shows, it was especially acute in travel writing where physical proximity and some sort of familiarity were almost inevitable, and it can be detected in the writings of slave-owners such as Edward Long, discussed by Miles Ogborn, for whom a certain sort of distance seems to have been necessary in a multiracial society. More generally, as Sachs shows, Enlightened views of man placed great store on the observer's natural capacity for sympathy, a form of emotional identification, which needed to be tempered or controlled by what he, following Adam Smith, refers to as the notion of "the impartial spectator," a self-imposed ethical constraint or governor, intended to achieve what was thought of as an optimal distance. Moore's travel accounts, with their careful balance of sympathy and analysis, can be seen and may have been intended as an exemplary application of Smith's concept.

As our essays demonstrate, notions of distance were often connected to or governed by ideas about what constituted permissible evidence. Mark Phillips reminds us that history painting, in its pure neoclassical form, refused to represent the quotidian and the particular, seeing only the heroic and the universal as admissible subject matter. For William Robertson, indigenous art and local testimony lacked the authority of European chronicles, because philosophical history was a history of writing, and because primitive societies characterized by similarity only generated "immeasurable and tiresome" details. The facts were tedious because they were irrelevant in societies characterized by stasis. Similarly, as Ogborn shows, a white Englishman in Jamaica like Long could ignore or translate into a different idiom natural-historical knowledge produced by Africans or American natives because it relied on a survival instinct rather than on systematic thought. At the heart of such analyses is, of course, a Eurocentrism that denies others not only a history, but also the voice to express it. It is a pity that Moore did not travel outside, Europe, as it would have been interesting to see the extent and limits of his sympathy for "others."

It is in this drawing of boundaries and operation of exclusions that one sees most clearly the ideological impetus behind different forms of distancing. Sebastiani points to the importance of Robertson's Protestant providentialist narrative of the civilizing mission of the Europeans in the New World for his history. Ogborn uncovers the contorted strategies of Long, eager to portray the closeness of orangutans to Hottentots (they both have limited language), in order 
to create distance between civilized whites and less developed people of colour. The moral and juridical implications of distance, both in space and in time, weakening every sort of sentiment and compassion, have been subtly revealed by Carlo Ginzburg. ${ }^{14}$

Even if we are today aware of the problematic nature of historical evidence, from the point of view of both its subject matter and its methods, and more generally aware of the limits of historical discipline, we can agree that a degree of historical certainty lay at the heart of Enlightenment's attitude towards the past. At the same time, one can conjecture that, in the eighteenth century, European societies and their historians knew what they wanted to see or observe: they had acquired the conviction that, through the act of writing, they could embrace every aspect of human progress, on the basis of the archives $d u$ tout, from manners through laws, in Voltaire's formulation of Nouvelles considérations sur l'histoire (1744). A new conception of history, one that was both universal and progressive, took over from Scripture and the idea of the Fall, as well as from the naturalistic model based on the cycles of seasons or on the epochs of nature. Writing projects that adopted different time frames, historians took as their central question what was to be observed, and where it was to be observed from, in the light of direct or indirect knowledge about the object of observation.

A vigorous debate about whether temporal distance was based on spatial distance resolved itself around the principle of the oneness of the human species and the different steps it has reached in different seats: the historiography shaped by the Enlightenment was every bit as diachronic as synchronic, so that different stages were manifest in different places. Thus the paradigm of distance bore a double weight, both temporal and spatial, acquiring, as the philosopher Collingwood put it, "the habit of spatializing time."15

We can see that historians approached the question of distance in a different way in the eighteenth century. The proliferation of studies into regions far distant from Europe (the tropical Pacific), and the extension of zones of contact with new worlds and peoples (the hinterlands of continental America, the Asiatic territories of Russia) led them to enlarge their vision, helping them to think globally. Yet the opening up of the object of history, making it virtually universal, provoked new questions. What was it that the historian was able or wished to see and in what way: through direct observation, through the eyes of others, or by the measurement of data (and, if so, which)? What sort of distancing would

14 Ginzburg, "To Kill a Chinese Mandarin: The Moral Implications of Distance," chap. 8 of Ginzburg, Wooden Eyes.

15 Robin G. Collingwood, The Idea of History (Oxford and New York, 1994; first published 1946), 364 . 


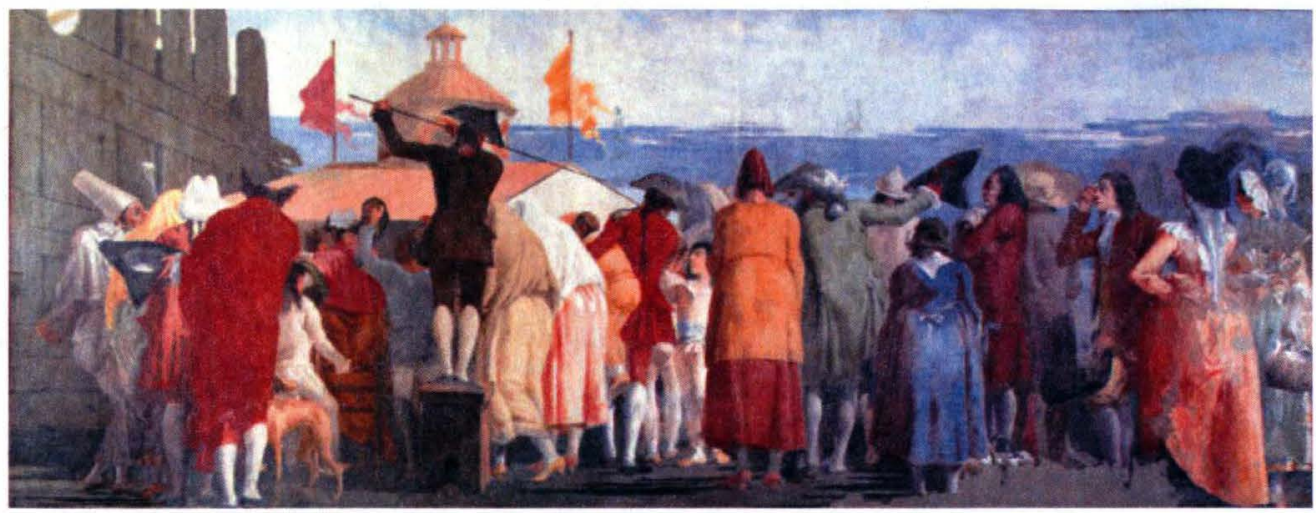

Fig. 1. (Colour online) Giandomenico Tiepolo, Il Mondo Nuovo, 1791, Inv. CI. I n. 1742 Ca' Rezzonico Museum of Eighteenth-Century Art, Venice. Photograph provided by the Archivio Fotografico, Fondazione Musei Civici di Venezia.

produce an agreed sense of what constituted history, and, conversely, how does distance produce distorted points of view?

In his fresco Il Mondo nuovo (Fig. 1), the eighteenth-century Venetian painter Giandomenico Tiepolo presents us with several forms of viewing. ${ }^{16} \mathrm{He}$ depicts a crowd of men, women and children, nearly all with their backs to the viewer, who is unable to see what they can see. Some are looking into a magic lantern, a mondo nuovo, a private, minaturized, experience of viewing, manipulated by a black-suited figure who wields a rod, creating the illusion that the distant is near. Other spectators, apparently waiting for their turn to use the magical machine, seem to look beyond the shoreline, peering into an ocean beyond which we can imagine another mondo nuovo. It is tempting to see Tiepolo's image as an echo of many of the preoccupations of writing about distance. Is it possible, with all the sophisticated tools and ideas at our disposal, to capture or reach what we wish to see, whether it is close or afar? Can we account for the new or does its proximity occlude our vision? Does not where we stand determine what we see? Tiepolo's playful meditation on viewing and distance alludes to many of the questions raised, in a variety of different ways, by the contributions in the following pages.

16 For a recent examination and contextualization of this fresco see Darius A. Spieth, "Giandomenico Tiepolo's 'Il Mondo Nuovo': Peep Shows and the 'Politics of Nostalgia,"' Art Bulletin, 92/3 (2010), 188-210. 